\title{
Survey and Detection of Candidatus Liberibacter asiaticus Causing Huanglongbing (HLB) Disease of Citrus in Manipur
}

\author{
Y. Herojit Singh ${ }^{1}$, Susheel Kumar Sharma ${ }^{2}$, Bireswar Sinha ${ }^{1 *}$, Ph. Sobita Devi ${ }^{1}$, \\ K. Mamocha Singh ${ }^{1}$, A. Sapana Devi ${ }^{2}$ and K. Sarda Devi ${ }^{1}$ \\ ${ }^{I}$ Department of plant Pathology, College of Agriculture, Central Agricultural University, \\ Imphal, India \\ ${ }^{2}$ ICAR Research Complex for NEH Region, Manipur Centre, Imphal-795004, India
}

*Corresponding author

\begin{tabular}{|c|}
\hline Keywords \\
\hline $\begin{array}{l}\text { Blotchy mottle, Citrus } \\
\text { Psylla, Huanlongbing, } \\
\text { Incidence, Prevalence }\end{array}$ \\
\hline Article Info \\
\hline $\begin{array}{l}\text { Accepted: } \\
\text { 12 July } 2018 \\
\text { Available Online: } \\
10 \text { August } 2018\end{array}$ \\
\hline
\end{tabular}

A B S T R A C T
Huanglongbing (HLB), also known as the "greening disease" is a serious disease affecting major citrus growing groves in India as well as in the world. The presumptive causal agent is a fastidious, gram negative, $\alpha$ - subdivision of the proteobacteria named Candidatus Liberibacter asiaticus (CLas) transmitted by Asian citrus psylla (Diaphorina citri). Different symptoms varying from yellowing of leaves, whole branch (called yellow shoot disease in China),drying of twigs, yellow patches in newly emerged flushes, irregular patches of yellowing on leaves (blotchy mottle), rabbit ear like appearance of leave and mineral deficiency like symptoms (leave showing symmetrical pattern of chlorosis on both sides of mid rib) were mainly observed on different citrus species during the survey conducted at various citrus growing pockets of Manipur in the present study. The leaves of citrus tree exhibiting the symptoms akin to mineral deficiency and rabbit ear like appearance were tested positive for HLB infection. Out of total 40 samples tested from different parts of Manipur by normal conventional PCR using specific primer targeting partial 16S rDNA, 19 samples were tested positive (47.50\% infection) indicating high prevalence of HLB in different parts of Manipur. Highest percent infection of HLB was observed in Kachai Village, Ukhrul district, Manipur (72.72\%) followed by Noney region of Tamenglong District (50\% of tested samples were positive) and lowest incidence was recorded from Imphal West and East districts of Manipur (33.33\%of tested samples were positive). These findings indicated widespread prevalence of HLB in different citrus growing pockets of Manipur.

\section{Introduction}

Huanglongbing (HLB) is a bacterial disease of citrus showing diverse symptoms ranging from yellowing of leaves, branches, drying of twigs, yellow patches on newly emerged flushes, irregular patches of yellowing on leaves (blotchy mottle), mineral deficiency like symptoms (leaves showing symmetrical pattern of chlorosis on both sides of mid rib), rabbit ear like appearance of leave etc. HLB has different names in different countries viz. vein phloem degeneration or phloem necrosis (Indonesia), Likubin (Taiwan), dieback 
(India), mottle leaf (Philippines) and greening (South Africa). Chinese name is the worldwide accepted one (Moreno et al., 1996). The disease has been reported as most destructive and devastating in India where more than 60 million trees have estimated to be wiped out due to this disease (Das et al., 2004).

The presumptive causal organisms of HLB are fastidious, phloem limited, gram-ve, alpha protobacterium which is classified as genus Candidatus Liberibacter (Bove, 2006). There are three forms of HLB pathogen: Asiatic form known as Candidatus Liberibacter asiaticus (CLas), African form known as Candidatus Liberibacter africanus (CLaf) and American form known as Candidatus Liberibacter americanus (CLam) (Jagouex et al., 1994, Gannier et al., 1984). A sub-species (CLaf sub sp. carpensis) was recorded from cape chestnut (Calodendrum carpense) in South Africa. Mixed infections of three forms of HLB may sometimes occur (Bove 2006). HLB is transmitted by two phloem-feeding insect vectors, the Asian citrus psyllid, Diaphorina citri and the African citrus psyllidor two-spotted citrus psyllid, Triozaerytreae (Bove, 2006). CLas bacterium has a wide host range and can infect, although not necessarily cause disease, on most rutaceous species and some solanaceous species (Halbert and Manjunath, 2004). The Asiatic and American types are transmitted by Asian citrus psylla (Diaphorina citri) and African type by Tryozaerytreae. The CLaf is heat sensitive and does not cause symptoms at temperatures greater than $25-30^{\circ} \mathrm{C}$. The CLas primarily distributed in Asia, is heat tolerant and able to cause symptoms even at temperatures greater than $35^{\circ} \mathrm{C}$ and is considered to be the most destructive one. The CLam appears heat sensitive similar to that of the CLaf. The HLB has emerged as one of the most important diseases in citrus plantation of different parts of the world. Disease has been reported from different citrus growing belts of India including North East India (Das et al., 2004; Ghosh et al., 2015). A few samples of CLas collected from different states of NE India and characterized at molecular level except for Manipur (Ghosh et al., 2015). Although based on symptoms, the disease is quite prevalent in different citrus orchards of Manipur, the systematic investigation of survey and detection has not been undertaken. The present study was therefore undertaken to study the prevalence of CLas infection in different citrus groves of Manipur.

\section{Materials and Methods}

Survey for huanglongbing disease at different citrus growing groves of Manipur

Systematic surveys were conducted at different citrus growing groves of Manipur. The districts covered were Imphal West (NaoremLeikai and Chajing), Imphal East (Thongju, Khabam and Top Awangleikai), Tamenglong (Noney) and Ukhrul (Kachai) during 2017 to 2018. During the surveys, symptom expression on different citrus species was recorded. Symptomatic samples suspected to have HLB infection were collected and immediately store din cool box to avoid the degradation of DNA. The collected samples were brought to laboratory and processed either immediately or stored in the DNA later solution at $-20^{\circ} \mathrm{C}$ or $-80^{\circ} \mathrm{C}$ for future use.

\section{Detection of CLas bacterium associated with huanglongbing disease of citrus in Manipur}

Total DNA was extracted from the mid rib, petiole of the collected samples using Plant DNeasy mini kit (Qiagen, Germany). DNA was isolated following two validated protocols viz., DNeasy Plant Mini Kit (Qiagen, Germany) or CTAB extraction protocol. 
CTAB method gave good yield of DNA but low quality as compared to QiagenDNeasy Plant Mini Kit. DNA isolation using DNeasy Plant Mini was done following the manufacturer protocol using column for DNA isolation. $100 \mathrm{mg}$ of samples were used for DNA extraction. The quality and quantity of the isolated DNA was determined by taking OD value at $260 \mathrm{~nm}$ and $280 \mathrm{~nm}$ using a NanoVuePlus Spectrophotometer (JENWAY Genova Nano, United Kingdom).

\section{PCR amplification}

Amplification was performed in Thermal cycler (Applied Biosystems) through conventional PCR using primers set LASF/R (Fujikawa and Iwanami, 2012) targeting partial 6SrDNA (most conserved region of the CLas genome). The reaction mixture was prepared for $25 \mu \mathrm{l}$ volume using $5 \mu \mathrm{l}$ of $10 \mathrm{x}$ buffers, $0.5 \mu \mathrm{l}$ of dNTPs $(10 \mathrm{mM})$ and $2.0 \mu \mathrm{l}$ $\mathrm{MgCl}_{2}(25 \mathrm{mM}), 2.0 \mu \mathrm{l}$ of forward and reverse primers $(10 \mu \mathrm{M}), 0.3 \mu \mathrm{l}$ Taq polymerase $(5$ units $/ \mu 1$, Genei $\left.{ }^{\mathrm{TM}}\right)$, DNA template of $5 \mu \mathrm{l}$ $(100-200 \mathrm{ng} / \mu \mathrm{l})$ and remaining volume was make up with nuclease free water. The thermal cycling conditions were: initial denaturation of $94^{\circ} \mathrm{C}$ for $4 \mathrm{~min}$, followed by 30 cycles of $94^{\circ} \mathrm{C}$ for $45 \mathrm{~s}$, annealing temperature of $56^{\circ} \mathrm{C}$ for $45 \mathrm{~s}, 72^{\circ} \mathrm{C}$ for $1 \mathrm{~min}$ and final extension at $72^{\circ} \mathrm{C}$ for $10 \mathrm{~min}$. The amplification product was analyzed at $1 \%$ agarose gel containing ethidium bromide in Tris acetate EDTA buffer. The amplicons were checked through UV illumination in gel documentation system.

\section{Results and Discussion}

\section{Survey of huanglongbing disease at different citrus growing pockets of Manipur}

Most the samples were collected during the cooler season of the year as concentration of
CLas bacterium was expected to be high during these periods. During the survey, diverse symptoms varying from yellowing of leaves, branches, rabbit ear like appearance of leaves, shoot with yellow patches, irregular mottling on leaf lamina (blotchy mottle), mineral deficiencies like symptoms (regular pattern of yellowing or vein yellowing or clearing on leaf lamina) were observed. Most interestingly leaves with mineral deficiency like symptoms and rabbit ear like appearance were found positive for CLas.

The irregular blotching called mottling and chlorosis are the characteristics symptoms of HLB (Baranwal, 2004). These findings indicated that CLas isolates prevalent in Manipur exhibit different symptoms under field conditions. All the citrus species collected from different surveyed areas were susceptible to HLB as reported earlier (Garnier and Bove, 1993). The different symptoms as observed under field conditions in the present study might be due to the prevalence of diverse strains/haplotypes of CLas bacterium and susceptibility patterns of the citrus genotypes (Tsai et al., 2008).

\section{Detection of CLas bacterium associated with huanglongbing disease of citrus in Manipur}

Detection of CLas bacterium was by PCR employing the primer targeting partial $16 \mathrm{~S}$ rDNA (most conserved region of CLas bacterium genome). The expected amplicon of approx. 500bp observed on the agarose gel was observed in the citrus samples having CLas infection. Out of the 37 samples collected from different locations of citrus growing pockets of Manipur, 19 samples were tested positive (54.16\% percent infection). The details of the samples, symptoms expression at field level, host plant are given in Table 1. 
Table.1 Survey and detection of CLas bacterium associated at different locations of Manipur

\begin{tabular}{|c|c|c|c|c|c|}
\hline $\begin{array}{l}\text { Sl. } \\
\text { No }\end{array}$ & Locations & District & Host & Symptoms & $\begin{array}{l}\text { HLB } \\
\text { infection }\end{array}$ \\
\hline 1 & Thongju & Imphal East & Acid Lime & Drying of twigs & -ve \\
\hline 2. & Thongju & Imphal East & Mandarin & $\begin{array}{l}\text { Yellowing } \text { and mineral } \\
\text { deficiency like symptoms on } \\
\text { leaves }\end{array}$ & $-v e$ \\
\hline 3 & $\begin{array}{l}\text { Top } \\
\text { AwangLeikai }\end{array}$ & Imphal East & Acid lime & $\begin{array}{l}\text { Irregular yellow patches on } \\
\text { leaves (blotchy mottling) }\end{array}$ & -ve \\
\hline 4. & $\begin{array}{l}\text { Top } \\
\text { AwangLeikai }\end{array}$ & Imphal East & Acid lime & $\begin{array}{l}\text { Yellowing and mottling of } \\
\text { leaves }\end{array}$ & -ve \\
\hline 5. & NaoremLeikai & Imphal West & Mandarine & $\begin{array}{l}\text { Yellowing of leaves, drying of } \\
\text { twigs. }\end{array}$ & \\
\hline 6 & NaoremLeikai & Imphal West & Acid lime & $\begin{array}{l}\text { Irregular yellow patches on } \\
\text { leaves (blotchy mottling) }\end{array}$ & $-v e$ \\
\hline 7. & Chajing1 & Imphal West & $\begin{array}{l}\text { Assam } \\
\text { Lemon }\end{array}$ & $\begin{array}{l}\text { Yellowing and mottling of } \\
\text { leaves }\end{array}$ & +ve \\
\hline 8. & Chajing2 & Imphal West & Acid Lime & $\begin{array}{l}\text { Blotchy mottle and mineral } \\
\text { deficiency like symptoms on } \\
\text { leaves }\end{array}$ & -ve \\
\hline 9. & Chajing3 & Imphal West & $\begin{array}{l}\text { Assam } \\
\text { Lemon }\end{array}$ & $\begin{array}{l}\text { Irregular patches of yellowing of } \\
\text { leaves }\end{array}$ & +ve \\
\hline 10. & Chajing4 & Imphal West & Pumello & $\begin{array}{l}\text { Irregular patches of yellowing of } \\
\text { plants }\end{array}$ & -ve \\
\hline 11. & Chajing5 & Imphal West & Mandarin & $\begin{array}{l}\text { Mineral deficiency like } \\
\text { symptoms on leaves }\end{array}$ & -ve \\
\hline 12. & Chajing6 & Imphal West & Acid lime & $\begin{array}{l}\text { Yellowing of leaves and mineral } \\
\text { deficiency like symptoms }\end{array}$ & +ve \\
\hline 13. & Chajing7 & Imphal West & $\begin{array}{l}\text { Sweet } \\
\text { orange }\end{array}$ & $\begin{array}{l}\text { Mineral deficiency like } \\
\text { symptoms on leaves }\end{array}$ & -ve \\
\hline 14. & Chajing8 & Imphal West & Acid Lime & $\begin{array}{l}\text { Yellowing and mottling of } \\
\text { leaves }\end{array}$ & $+v e$ \\
\hline 15. & Khabam & Imphal East & Acid Lime & Blotchy mottle on leaves & +ve \\
\hline 16. & Khabam & Imphal East & Acid Lime & $\begin{array}{l}\text { Yellowing and Mineral } \\
\text { deficiency like symptoms }\end{array}$ & $-v e$ \\
\hline 17. & NaoremLeikai & Imphal West & Acid lime & $\begin{array}{l}\text { Irregular patches of yellowing } \\
\text { leaves }\end{array}$ & $-v e$ \\
\hline 18. & NaoremLeikai & Imphal West & $\begin{array}{l}\text { Sweet } \\
\text { orange }\end{array}$ & $\begin{array}{l}\text { Mineral deficiency like } \\
\text { symptoms on leaves }\end{array}$ & $-v e$ \\
\hline 19. & NaoremLeikai & Imphal West & Acid Lime & $\begin{array}{l}\text { Irregular patches of yellow on } \\
\text { leaves and irregular chlorosis }\end{array}$ & -ve \\
\hline
\end{tabular}




\begin{tabular}{|c|c|c|c|c|c|}
\hline 20. & Naorem Leikai1 & Imphal West & Acid Lime & $\begin{array}{l}\text { Mineral deficiency like } \\
\text { symptoms on leaves }\end{array}$ & + ve \\
\hline 21. & Naorem Leikai2 & Imphal West & Acid Lime & Yellowing, mottling of leaves & +ve \\
\hline 22. & Noney-1 & $\begin{array}{l}\text { Tamenglong } \\
\text { district }\end{array}$ & $\begin{array}{l}\text { Sweet } \\
\text { orange }\end{array}$ & $\begin{array}{l}\text { Mineral deficiency like } \\
\text { symptoms, yellowing of leaves }\end{array}$ & +ve \\
\hline 23. & Noney-2 & $\begin{array}{l}\text { Tamenglong } \\
\text { district }\end{array}$ & Pumello & $\begin{array}{l}\text { Yellow patches on the surface of } \\
\text { leaves }\end{array}$ & -ve \\
\hline 24. & Noney-3 & $\begin{array}{l}\text { Tamenglong } \\
\text { district }\end{array}$ & Mandarin & Yellowing of leaves & -ve \\
\hline 25. & Noney-4 & $\begin{array}{l}\text { Tamenglong } \\
\text { district }\end{array}$ & Mandarin & $\begin{array}{l}\text { Red rust like symptoms on the } \\
\text { leaf lamina }\end{array}$ & -ve \\
\hline 26. & Noney-5 & $\begin{array}{l}\text { Tamenglong } \\
\text { district }\end{array}$ & Acid Lime & $\begin{array}{l}\text { Yellowing of leaves and mineral } \\
\text { deficiency like symptoms }\end{array}$ & +ve \\
\hline 27. & Noney-6 & $\begin{array}{l}\text { Tamenglong } \\
\text { district }\end{array}$ & $\begin{array}{l}\text { Assam } \\
\text { Lemon }\end{array}$ & Intervienalchlorosis on the leave & +ve \\
\hline 28. & Noney-7 & $\begin{array}{l}\text { Tamenglong } \\
\text { district }\end{array}$ & Pumello & Yellowing of whole tree & -ve \\
\hline 29. & Noney-8 & $\begin{array}{l}\text { Tamenglong } \\
\text { district }\end{array}$ & Pumello & $\begin{array}{l}\text { Mineral deficiency like } \\
\text { symptoms }\end{array}$ & +ve \\
\hline 30. & Kachai(K-1) & Ukhrul & $\begin{array}{l}\text { Kachai } \\
\text { Lemon }\end{array}$ & $\begin{array}{l}\text { Rabbit ear like appearance of } \\
\text { leave and yellowing of leaves }\end{array}$ & + ve \\
\hline 31. & Kachai(K-2) & Ukhrul & $\begin{array}{l}\text { Kachai } \\
\text { Lemon }\end{array}$ & $\begin{array}{l}\text { Irregular Chlorosis, mineral } \\
\text { deficiency like symptoms on } \\
\text { leaves }\end{array}$ & +ve \\
\hline 32. & Kachai(K-3) & Ukhrul & $\begin{array}{l}\text { Kachai } \\
\text { Lemon }\end{array}$ & Yellowing of whole leaves & -ve \\
\hline 33. & Kachai(K-4) & Ukhrul & $\begin{array}{l}\text { Kachai } \\
\text { Lemon }\end{array}$ & $\begin{array}{l}\text { Mottling, Yellowing, Mineral } \\
\text { deficiency like symptoms on } \\
\text { leaves }\end{array}$ & +ve \\
\hline 34. & Kachai(K-5) & Ukhrul & $\begin{array}{l}\text { Kachai } \\
\text { Lemon }\end{array}$ & $\begin{array}{l}\text { Mottling and yellowing of } \\
\text { leaves }\end{array}$ & + ve \\
\hline 35. & Kachai(K-6) & Ukhrul & $\begin{array}{l}\text { Kachai } \\
\text { Lemon }\end{array}$ & $\begin{array}{l}\text { Mottling and yellowing of } \\
\text { leaves }\end{array}$ & +ve \\
\hline 36. & Kachai(K-7) & Ukhrul & $\begin{array}{l}\text { Kachai } \\
\text { Lemon }\end{array}$ & Yellowing of whole leaves & -ve \\
\hline 37. & Kachai (K-8) & Ukhrul & $\begin{array}{l}\text { KachaiLe } \\
\text { mon }\end{array}$ & $\begin{array}{l}\text { Mottling, yellowing of whole } \\
\text { leaves }\end{array}$ & +ve \\
\hline 38. & Kachai (K-8) & Ukhrul & $\begin{array}{l}\text { Kachai } \\
\text { Lemon }\end{array}$ & Yellowing of whole leaves & + ve \\
\hline 39. & Kachai (K-8) & Ukhrul & $\begin{array}{l}\text { Kachai } \\
\text { Lemon }\end{array}$ & $\begin{array}{ll}\text { Irregular chlorosis, mineral } \\
\text { deficiency like symptoms on } \\
\text { leaves }\end{array}$ & +ve \\
\hline 40 . & Kachai (K-8) & Ukhrul & $\begin{array}{l}\text { Kachai } \\
\text { Lemon }\end{array}$ & Yellowing of whole leaves & -ve \\
\hline
\end{tabular}


Table.2 Prevalence of CLas bacterium based on 16S rDNA

\begin{tabular}{|l|l|l|c|c|}
\hline Sl.no. & Region/districts & $\begin{array}{l}\text { Total } \\
\text { samples collected }\end{array}$ & $\begin{array}{l}\text { No. of sample tested } \\
\text { positive for HLB }\end{array}$ & $\begin{array}{l}\text { Incidence of HLB } \\
(\%) *\end{array}$ \\
\hline 1. & Imphal West & 15 & 5 & 33.33 \\
\hline 2. & Imphal East & 6 & 2 & 33.33 \\
\hline 3. & Tamenglong & 8 & 4 & 50.00 \\
\hline 4. & Ukhrul & 11 & 8 & 72.72 \\
\hline & Total & $\mathbf{4 0}$ & $\mathbf{1 9}$ & $\mathbf{4 7 . 5 0}$ \\
\hline
\end{tabular}

*PCR based detection

The percent infection of HLB was highest at Kachai village of Ukhrul (72.72\%) followed by Noney in Tamenglong district (50\%). The lowest per cent infection was recorded from the samples collected from Imphal West and Imphal East districts with $33.33 \%$ infection (Table 2). An incidence of 5-30\% in Sikkim and $5-8.3 \%$ on Khasi mandarin was earlier reported from NE India (Das et al., 2007). Ghosh et al., (2015) reported a HLB incidence of $32 \%$ in different areas surveyed in North East except Manipur. Present study showed high prevalence of HLB in Manipur and reported susceptibility of all citrus species to CLas. Present study also reported the applicability of PCR based detection in routine indexing of citrus for HLB infection. Future studies on characterization of HLB haplotypes will throw more light on the CLas population prevalent in Manipur

\section{Acknowledgement}

Authors are grateful to DBT for funding under Twinning program and Joint Director ICAR Manipur Centre and Director ICAR RC NEH for providing facilities.

\section{References}

Baranwal, V. K., Mazumder S, Singh, J., Suryanarayana, V., Ghosh, D. K. and Ahlawat, Y.S. (2004). PCR detection of Candidatus Liberibacter asiaticus, the agent of Huanglongbing or greening disease in citrus. Indian Phytopath., 57: 164-168.

Bove, J. M. (2006). Huanglongbing: a destructive, newly-emerging, centuryold disease of citrus. J. Plant Pathol. 88 (1), 7-37

Das, A. K., Singh, S. and Rao, C. N. 2007. Presence of citrus greening (Huanglongbing) disease and its psyllid vector in the North-Eastern region of India confirmed by PCR technique. Current science 92(12): 1759-1763.

Das, A.K. (2004). Rapid detection of Candidatus Liberibacter asiaticus, the bacterium associated with citrus Huanglongbing (Greening) disease using PCR. Current Sci., 87(9): 11831185.

Folimonova, S. Y., Robertson, C. J., Garnsey, S.M., Gowda, S. and Dawson, W. O. (2009). Examination of the responses of different genotypes of citrus to huanglongbing (citrus greening) under different conditions. Phytopathology 99: 1346-1354.

Fujikawa, T. and Iwanami, T. (2012). Sensitive and robust detection of citrus greening (huanglongbing) bacterium "Candidatus Liberibacter asiaticus" by DNA amplification with new $16 \mathrm{~S}$ rDNA-specific primers. Mol cell Probes. 26(5): 194-197.

Garnier, M. andBové, J.M. (1993). Citrus greening disease and the greening bacterium. In: Moreno P, da Graça JV, 
Timmer LW (eds), Proceedings of the Twelfth Conference of the International Organization of Citrus Virologists, New Delhi, India, 23-27 November 1992. Riverside: International Organization of Citrus Virologists, University of California, Riverside. pp. 212-219.

Garnier, M., Danel, N. and Bové, J. M. (1984).Etiology of citrus greening disease. Ann. Microbiol. 135A: 169 179.

Ghosh, D. K, Bhose, S., Warghane, S., Motghare, M., Sharma, A.K., Dhar, A.K. and Gowda, S. (2015). Loopmediated isothermal amplification (LAMP) based method for rapid and sensitive detection of 'Candidatus Liberibacter asiaticus' in citrus and the psyllid vector, Diaphorina citri Kuwayama. J. Plant Biochem. Biotechnol., DOI 10.1007/s13562-0150332-8.

Halbert, S.E. and Manjunath, K.L. (2004). Asian citrus psyllids (Sternorrhyncha: Psyllidae) and greening disease of citrus: A literature review and assessment of risk in Florida. $F l$. Entomol., 87(3): 330-353.

Jagoueix, S., Bove, J. M. and Garnier M. (1994). The phloem-limited bacterium of greening disease of citrus is a member of the alpha-subdivision of the Proteobacteria. Int. J. Syst. Bacteriol., 44(3): 379-386.

Moreno, P., da Graça, J. V. and Yokomi, R.K. (1996) Preface. In: da Graça JV, Moreno P, Yokomi RK (eds), Proceedings of the Thirteenth Conference of the International Organization of Citrus Virologists, Fuzhou, Fujian, China, 16-23 November $1995 . \quad$ Riverside: International Organization of Citrus Virologists, University of California: Riverside. pp. v-vi.

Tsai, C. H., Hung, T. H. and Su, H.J. (2008) Strain identification and distribution of citrus huanglongbing bacteria in Taiwan. Botanical studies 49: 49-56.

\section{How to cite this article:}

Herojit Singh Y., Susheel Kumar Sharma, Bireswar Sinha, Ph. Sobita Devi, K. Mamocha Singh, A. Sapana Devi and Sarda Devi, K. 2018. Survey and Detection of Candidatus Liberibacter asiaticus Causing Huanglongbing (HLB) Disease of Citrus in Manipur. Int.J.Curr.Microbiol.App.Sci. 7(08): 2427-2433. doi: https://doi.org/10.20546/ijcmas.2018.708.245 